\title{
SEMANTIC PROTOTYPES OF INDONESIAN STAPLE FOODS
}

\author{
Latif Amrullah \\ IAIN Tulungagung \\ email: amrullah.latif@gmail.com
}

\begin{abstract}
Semantic prototypes of staple foodsare different among community members in Indonesia. These differences can be affected by,among others, geographical and socio-cultural factors. Departing from these differences, this study aims to find out the semantic prototype formula of the staple food concept based on Indonesian people's perspectives. The study was carried out by distributing a questionnaire as a means of collecting data and the data were then quantitatively analyzed. Referring to the theories of Wierzbicka and Coleman \& Kay, the study reveals that Indonesian people still firmly believe that rice is an irreplaceable staple food. The proposed semantic prototypesare proved to have patterns similar to the findings. In addition, it turns out that cultural and natural factors also affect the way people interpret these staple foods.
\end{abstract}

Keywords: staple foods, semantic prototypes, Indonesian people

\section{PROTOTIPE SEMANTIK MAKANAN POKOK MASYARAKAT INDONESIA}

\begin{abstract}
Abstrak
Prototipe semantik makanan pokok memiliki perbedaan penafsiran di antara anggota masyarakat di Indonesia. Perbedaan tersebut dapat dipengaruhi oleh antara lain faktor geografis dan sosial budaya. Berangkat dari adanya perbedaan tersebut, penelitian ini bertujuan untuk menemukan formula prototipe semantik dari konsep makanan pokok berdasarkan cara pandang masyarakat Indonesia. Penelitian dilaksanakan dengan menyebarkan angket sebagai alat pengumpulan data dan data kemudian dianalisis secara kuantitatif. Dengan mengacu teori Wierzbicka dan Coleman dan Kay, penelitian ini mengungkap bahwa masyarakat Indonesia masih berpegang teguh bahwa nasi merupakan makanan pokok yang tidak tergantikan. Prototipe semantik yang diajukan dalam penelitian ini terbukti memiliki pola yang hampir sama dengan hasil penelitian. Disamping itu, ternyata faktor budaya dan alam sekitar turut mempengaruhi cara masyarakat menafsirkan bahan makanan pokok tersebut.
\end{abstract}

Kata kunci: makanan pokok, prototipe semantik, masyarakat Indonesia 


\section{INTRODUCTION}

This paper is conducted under the notion of Semantics, specifically the semantic prototype. Indonesia staple food, as part of local culture, varies one place from others. Its unique environment and weather create different mind-constructing concepts on staple food. Some foodstuffs can only be planted in particular island and places, meaning that the limitation of nature gives people a chance to explore and exhibit their perception and abilities. Above all kinds of staple foods, some of them are considered to be the most consumed-staple foods. It means that a foodstuff can be called as staple food if it meets certain requirements created by society and preserved in every person's perception.

As a branch of Linguistics, Semantics has a close relationship with the meaning of a word. The position of Semantics is different from the other branches of Linguistics, such as Syntax or Pragmatics. According to Verhaar (2004: 385), Semantics is classified into two scopes of study, namely the Grammatical Semantics and Lexical Semantics. The smallest unit that can be studied under Grammatical Semantics is forming words morpheme, while Lexical Semantics focuses on the study of meaning in relation with the dictionary. Talking about lexical meaning, Saussure (via Chaer, 1995:29) argues that the meaning is composed by two elements, i.e. signified and the signifier. Signifier is the sounds that form of phonemes, while signified is a concept or meaning of a sound. Then it could be said that every linguistic sign consists of sound and meaning elements.
Concept as a referent of a word is never perfectly suit in accordance with the demands of its speakers. The concept constantly moves and changes in line with the meaning of a word. When someone states "staple food", then people wonder "Which staple foods?". Therefore, it encourages the speakers to provide and formulate a concept that exist in their mind for the purpose of limiting or defining, even though the definition is not necessarily true and strong (Chaer, 1995: 39). Because it is true that language and mind cannot be separated one from another: just like a coin with two sides (Baehaqi, 2017: 203). In terms of providing a clear formulation about something, there are several ways that can be conducted, such as by the naming process, terming, defining (Chaer, 1995:43). Along with the development in Linguistics, many experts do not agree to the above process, because the process is only limited to the meaning in the dictionary. Meanwhile, if it is examined further, the explanation contained in the dictionary cannot accommodate the whole and the complex meaning it has.

Due to the development of discontent, there is a tendency among linguists to propose a better approach, the approach which generally classifies a word in the form of thesaurus and componential analysis approach. The thesaurus approach tries to assess and classifies the concepts into schematic form, then each scheme is divided into smaller portions. While the componential analysis approach divides the meaning into smallest components in a scheme, so it can be distinguished the two elements of lexical meaning, i.e. semantic markers and semantic 
differentiator (Cahyono, 1995:206). There is also an argument that actually humans think vaguely, in the sense that the referent of an object is very different from the words that represent it. According to the traditional school, a word actually can be defined. But in fact it was not approved since the rose of a concept of "game" that was introduced by Wittgenstein in 1953 as stated in a book Philosophical Investigations which includes the concept of family resemblance. Then many years later, this idea became the rationale of the birth of the semantic prototype (Wierzbicka, 1992:22-23).

Kridalaksana (2011:203) states that the semantic prototype is a proposition that contains the most important features, compared to another object or other similar things. For example the concept of staple food, then there must be the most important features: a food which is consumed so that it can make someone feels full, and this characteristic is different from the concept of dessert, for example. In relation with the referent of a word, Parker (1986:36-37) gives a description of the four concepts that are useful in thinking and talking about the reference: referent, extension, prototype, and stereotype. In that explanation, it is mentioned that the prototype of a typical member of the expansion expression is the prototype of that kind of expressions. For example, a robin is included into bird prototype, while the ostrich or pelican, because each bird is different, is not included into the bird prototype.

Based on the problems of meaning, one would find it difficult to define a word because human create the word in the state of fuzziness and indetermination.
So what should people do with this case? Lyons (1995:96-97) proposes an answer that the native speaker of a language can be easily answered with what is called as prototype, and usually what they want to show is in accordance with the prototype. The idea of this prototype cannot be separated from the experts in psycholinguistic and this idea can be attributed to psychological research in case where cognitive categorization is learnt by an infant or child during their development until their maturity. While Coleman and Kay (1981:26) argues that the prototype's view from meaning of a word is trying to take into account the clear prehistoric intuition in which semantic frequency often has a vague scope and there are gradations on its members. In short, the application of this view is not merely the problem yes or no as it is given in checklist view, but it tends to be the more or less of a categorization.

From the above reasons, this article tries to find the semantic prototype from the concept of staple foods proposed by Indonesian society. By having an obvious prototype, it is expected that the research will help the government and also disseminate the public to be aware and to begin making use of staple foods other than rice and to support food diversification program. The linkage between the concepts of basic food and culture will be seen from the types of societies' interpretation on staple foods. For example, people who live in eastern Indonesia would probably include sago as their staple foods, while the western part of the Indonesian people will not. This difference is the semantic prototype associated with the staple foods of local culture. 


\section{RESEARCH METHOD}

When someone is asked to explain the concept of the staple food, what comes up in mind is the kind of dish that is always available and is served at meal time. In the sense of this proposition, then vegetables and side dishes should also be put as a staple food. But in fact societies' view is not at this ease. Although there are always vegetables for meals, but people do not declare it as a staple food because it does not satisfy if only eating vegetables. For this reason, another proposition is badly needed to reinforce the staple food meaning, a proposition which states that the food can satisfy the hunger.

A food can be regarded as a staple food when it cannot be substituted by other kinds of food. This irreplaceable position may happen due to its high nutritional content, or may be its availability in the nature, just like a study conducted by Mapandin (2006: 27) in District of Jayawijaya, Wamena. Just for an example, people who always eat rice and vegetables every morning before activities, it would be weird when they have to eat a sandwich and milk. Although both of them contain the same nutritional value, the digestive system will not feel the same way. Indonesian people will tend to feel full after eating rice in certain portions rather than eating bread. Then the second proposition is the irreplaceable staple food and tends to be a lot.

From the above brief description, the propositions that can be used in determining the staple foods are:

$\mathrm{X}$ is always available when eating $\mathrm{X}$ cannot be replaced and tends to be a lot
After eating $\mathrm{X}$, then the person will feel full

The above prototypes should be available in each of the staple food consumed by the people of Indonesia. Once the concept of staple food is understood, the next step is preparing the instruments so that the prototype of staple food will be well identified. In a research instrument that has been made, there are 6 parts of question that should be filled in by the respondents. The first part is respondents' identity, including age, gender, school, regency, province, and tribe. Age - which is an important parameter - will support in the understanding of language acquisition, particularly the mother language. Then the parameter of district is a factor that is very important because this study examines the influence of regional culture. From this point, it will be clearly seen a tendency among respondents related to the future understanding of the prototype of staple food.

In part two, the respondents were asked to assess whether the ten foodstuffs mentioned are their staple food, in which respondents simply put a check mark at the column provided. The ten kinds of foodstuffs are staple food that is commonly consumed by Indonesian people in general and is the result of observation and mental knowledge of the author. In order to obtain a more complete description, the author includes the third-part questions by giving a score ranging from 1 to 10 on the staple food as it is stated in section five. With this type of question, it is expected that the respondent will make a gradation in grouping staple food based on their own mental knowledge. 
In part four, respondents were asked to demonstrate the knowledge on staple food processing which is taken from part two. The more knowledge owned by respondents regarding the staple food, the more it will show their ability in understanding the local culture. For example, Javanese people may assume that sago can only be processed into papeda, whereas for Papuanese it can be processed into sago chips, for example. Furthermore, in part five, there are three closed questions and two open-ended questions. This part aims to determine the respondents' tendency to a case and also their knowledge. The last part is an open question: the respondents were asked to write down requirements that a food can be referred to as a staple food based on the knowledge they have.

\section{RESULTS AND DISCUSSIONS}

The questionnaires were distributed to a number of high school students alumni who were studying in Yogyakarta. They do not only come from Yogyakarta, but also from Wonosobo, Lampung, Manggarai, Medan, and other areas, which means that it has an apportionment population distribution. This information was obtained from the question section one: the identity of respondents. After the questionnaires were examined further, it was found that 25 questionnaires were ready to be analyzed.

In part two, the respondents were asked to give an assessment whether the foodstuffs are eligible to be categorized as staple food. After calculating process, it is found that rice is still the main referent of the concept of staple food in society. Below is a table of the calculation ( $\mathrm{SS}=$ strongly agree; $\mathrm{S}=$ agree; TS=disagree; STS=strongly disagree).

Table 1. Categorization of basic foodstuffs

\begin{tabular}{clcccccc}
\hline No & Foodstuffs & SS & S & $\sum+$ & TS & STS & $\sum-$ \\
\hline 1 & Potato & 3 & 17 & 20 & 5 & 0 & 5 \\
2 & Wheat & 2 & 17 & 19 & 5 & 1 & 6 \\
3 & Corn & 3 & 15 & 18 & 7 & 0 & 7 \\
4 & Rice & 16 & 9 & 25 & 0 & 0 & 0 \\
5 & Noodle & 1 & 11 & 12 & 10 & 3 & 13 \\
6 & Yam & 1 & 14 & 15 & 10 & 0 & 10 \\
7 & Sago & 2 & 8 & 10 & 11 & 4 & 15 \\
8 & Taro & 1 & 9 & 10 & 12 & 3 & 15 \\
9 & Cassava & 4 & 16 & 20 & 5 & 0 & 5 \\
10 & Nut & 2 & 12 & 14 & 8 & 3 & 11 \\
\hline
\end{tabular}

Positive sigma means that the food is agreed to be considered as staple food, whereas negative sigma shows that these foodstuffs are not included as staple food. The above table shows that the rice was approved by 25 respondents as the staple food. The number of respondent who puts rice into staple food shows that the irreplaceable staple food proposition is clearly reflected 
in this question. Although it can be replaced with other basic foodstuffs, only some of which can replace rice, such as wheat, corn, potato, or cassava. Some staple foods however, such as noodle, potato, sago and taro which in negative sigma, have only relatively small differences compared to positive sigma.

Having examined the information variables of respondents, the result shows that the high negative sigma of sago and taro tends to come from the western Indonesia societies, such as East Kalimantan, Java, South Sumatra, Lampung, Jambi, or Aceh. The positive sigma of both types of foodstuff is the respondents' choice from Eastern Indonesia, such as Ambon and Papua. Therefore, these differences indicate that the pattern of culture from both Western and Eastern Indonesia is constructed by itself in such a way so that it adapts to the conditions of their life environment. Culture, lifestyle, and habits have formed the mindset and affect their referents to the basic concept of foodstuff.

Table 2. Rating of basic foodstuffs

\begin{tabular}{cc}
\hline Rank & Foodstuffs \\
\hline 1 & Rice \\
2 & Potato \\
3 & Cassava \\
4 & Corn \\
5 & Wheat \\
6 & Yam \\
7 & Sago \\
8 & Taro \\
9 & Nut \\
10 & Noodle \\
\hline
\end{tabular}

This proposition is also supported by the results shown from question section 2: the respondents were asked to rank the most suitable foodstuffs to be called as a staple food.

The rank shows that rice as the proposition of Indonesia staple food seems in no doubt. It is proved that a foodstuff which has the highest positive sigma in table 1 is also ranked as the highest in table 2 above. So it can be concluded that the referent of the Indonesia staple food is still around the existence of rice, potato, yam, corn, and wheat. This is not surprising because most of the land in Indonesia is suitable to plant crops such as rice, corn, wheat, cassava, and potato, accordingly the referent of staple food is very dependent on these foodstuffs. Moreover, its position is irreplaceable with other basic foodstuffs.

While noodle, corn, and taro have not become a referent of staple food due to the large value of negative sigma indicating a rejection from respondents to consider these foodstuffs as a staple food. This low rating happens perhaps because not all regions in Indonesia are able to develop and grow these crops, its availability in market, its low nutritional substance, or simply because people do not feel quite full when eating only those staple foods. It is interesting to note that noodle is at the lowest rank and it must signify something. It seems people have started realizing the negative effects of eating any kinds of instant noodles. Besides its low vitamins and nutrient, some noodle also contains preservatives that are harmful for body. This is most likely influenced by respondents' age and education level they have. In addition, only eating noodle is also 
unable to make someone satisfied as same as rice.

For the third preposition: after eating $\mathrm{X}$ then someone will feel satisfied, the answers were gathered from the closed questions in section 5. The author tried to avoid the use of rice as the referent on these simulated situations since rice is assumed as staple food that cannot be replaced. The three questions are:

(1) At breakfast time, you eat a loaf of bread. Do you feel that you have eaten yet?

(2) At lunchtime, you eat some boiled potatoes from home. Do you feel that you have eaten yet?

(3) In the dinner, you eat fried noodles without modification. Do you feel that you have eaten yet?

Table 3. Answers to three questions related propositions

\begin{tabular}{ccc}
\hline Question & Yes & No \\
\hline 1 & 12 & 13 \\
2 & 11 & 14 \\
3 & 19 & 6 \\
\hline
\end{tabular}

For some people, eating bread as breakfast is not satisfied enough, or perhaps that is not what we call as breakfast. Although the gap is relatively small, the respondents who answered "yes" associated with the first question mostly come from Java and Sumatra. It can also be influenced by the availability of bread in that area or the economic level that makes people accustomed to eating bread. It signifies that their culture creates a constellation of thinking and behavior as their living conditions. For those who answered "no" in the second proposition - that X cannot be replaced and tends to be a lot - is invalid. Bread is not considered as staple food, therefore the position can be replaced or even it is just a substitution for rice at a particular time. It is also possible that they do not feel satisfied because carbohydrates contained in bread is not as much as on rice, as we know that carbohydrates is essential for daily activities and energy.

On the next situation, eating steamed potatoes from home during the lunch hour, 14 respondents consider it as unsatisfied condition. This may happen since potato does not be regarded as staple food just like bread. Because energy needed in the morning and afternoon is high enough, it requires a high carbohydrate intake as well. Similarly, the third proposition is yet to be met, because they feel not having a meal when eating potato. However, it is reasonable since the rank of wheat and potato is under the rice and both of them have a high positive sigma.

However, there is an anomaly in the third situation where many respondents feel that they have eaten when they only eat fried noodles without any side dish at the evening. Compared to Table 1 and Table 2, the noodle should not make someone full because it has a high negative sigma and it ranks as the most basic categorization of the staple food. This probably happens because at night eating rice is too heavy since the carbohydrate consumed into the body is unused. In addition, consuming wheatbased noodle which contains average carbohydrate nutrient is enough to make someone full at night.

Overall, the foodstuffs which have a positive sigma are ranked as the highest level in staple food categorization. This is the reason why the referents of staple food are only focused on five types of 
those foods. In fact, when we study further, some foodstuffs such as cassava, sago, or taro can be also an alternative of staple foods amid the threat of food crisis. Conversely, foodstuffs that have a high negative sigma tend to be deemed as not satisfying when being eaten because people are still thinking that what the so-called eating is when they feel full by eating staple foods that are at high positive sigma. That is why people construct the referents of staple food differently. In addition, there is a link between the type of staple foods eaten and the meal times. The three questions above use different staple food randomly, then it is put in a specific meal times. Surely it will be more complete thoroughly when staple food is presented in different situations such as at breakfast, lunch and dinner so there will be similarities in the treatment of research instruments.

\section{CONCLUSION}

From this research, some conclusions can be drawn related to the prototype semantics of staple food in Indonesia society. The first, people still consider that rice is the most important and irreplaceable food commodities. This is understandable because most of farmers in Indonesia plant rice with its various varieties. However, this practice will be bad if the rice consumption is getting higher and the crop land reduces its size. The bad effect is that it will worsen the food crisis nationally. That is why the presence of this study can help governments and communities to change the paradigm of staple food consumption from rice to other foodstuffs in order to diversify the alternative staple foods such as potato, corn, cassava or wheat.

Second, the prototypes proposed tend to correspond with the results that have been carried out from this research. The prototypes that must exist and be the characteristic of staple foods are: $\mathrm{X}$ cannot be replaced and tends to be a lot, and after eating $X$ then the person will feel full. The first proposition has been proven as the results in Table 1 and Table 2 , while the third proposition has been proved in Table 3 . The first proposition is related to the outside-world referent, which is what are being the culture and the cognition of society to the staple food. While the second proposition relates to the referent of self-perception when eating these foods whether it makes someone feels full. For further improvements, the following research can enrich the variables affecting the consumption of staple food in society and also can improve the data collecting instruments. In addition, the research on the existence of staple food seems to be related to the time when a person eats. Mealtimes will affect whether people feel full. Besides, people will have different concepts and referents of the staple food.

\section{ACKNOWLEDGEMENTS}

The writer would like to express his appreciation to those who help in finishing this article. Expression of gratitude is addressed to Rector of State Islam Institute of Tulungagung who gave support for a better academic atmosphere. He is also grateful to the respondents for giving a trusted data for this research. 


\section{REFERENCES}

Baehaqie, Imam. 2017. "Makna Semiotis Nama-nama Makanan dalam Sesaji Selamatan Tingkeban di Dukuh Pelem, Kabupaten Wonogiri," dalam Litera Volume 16 (02): 203-216.

Cahyono, Bambang Yudi. 1995. KristalKristal Ilmu Bahasa. Surabaya: Airlangga University Press.

Chaer, Abdul. 1995. Pengantar Semantik Bahasa Indonesia. Jakarta: Rineka Cipta.

Kridalaksana, Harimurti. 2011. Kamus Linguistik. Jakarta: Gramedia Pustaka Utama.

Linda, Coleman and Paul Kay. 1981. Prototype Semantics: The English Word Lie. Language 57 (1): 6-44. In Semantics Linguistics 2008. Departments of Linguistics, ANU.

Lyons, John. 1995. Linguistic Semantics: An Introduction. Cambridge: Cambridge University Press.
Mapandin, Wahida Y. 2006. Hubungan Faktor-Faktor Sosial Budaya dengan Konsumsi Makanan Pokok Rumah Tanggan Pada Masyarakat di Kecamatan Wamena, Kabupaten Jayawijaya Tahun 2005. Thesis. Program Pascasarjana Universitas Diponegoro Semarang: Unpublished.

Parker, Frank. 1986. Linguistics for Non-Linguists. London: Taylor \& Francis.

Verhaar, J.W.M. 2004. Asas-Asas Linguistik Umum. Yogyakarta: Gadjah Mada University Press.

Wierzbicka, Anna. 1992. Semantics, Culture, and Cognition: Universal Human Concepts in Culture-Specific Configurations. New York: Oxford University Press. 